\title{
Risk Factors for Overweight and Obesity among Children Ages 0 to 3.5 Living in the Miramichi Public Health Region of New-Brunswick, Canada
}

\author{
Etienne Dako ${ }^{1 *}$, Louise Anin Atchibri ${ }^{2}$, Fabrice Mobetty ${ }^{1}$, Slimane Belbraouet ${ }^{1}$, \\ Guilaine Tchadieu Tchapya ${ }^{1}$, Lita Villalon ${ }^{1}$
}

\begin{abstract}
${ }^{1}$ Laboratory of Biotechnology and Human Nutrition, School of Food Science, Nutrition and Family Studies, Faculty of Health Science and Community Services, University of Moncton, New-Brunswick, Canada

${ }^{2}$ Laboratory of Nutrition and Food Safety, Department of Food Science and Technology, University of Nanguy Abrogoua, Abidjan, Ivory Coast
\end{abstract}

Email: ^Etienne.dako@umoncton.ca

How to cite this paper: Dako, E., Anin Atchibri, L., Mobetty, F., Belbraouet, S., Tchadieu Tchapya, G. and Villalon, L. (2017) Risk Factors for Overweight and Obesity among Children Ages 0 to 3.5 Living in the Miramichi Public Health Region of New-Brunswick, Canada. Food and Nutrition Sciences, 8, 334-347.

https://doi.org/10.4236/fns.2017.83023

Received: January 25, 2017

Accepted: March 26, 2017

Published: March 30, 2017

Copyright $\odot 2017$ by authors and Scientific Research Publishing Inc. This work is licensed under the Creative Commons Attribution International License (CC BY 4.0).

http://creativecommons.org/licenses/by/4.0/

\begin{abstract}
Obesity, a major risk factor in numerous pathologies, poses a public health problem. The objective of this study was to assess the prevalence of the risk of overweight, overweight and obesity, as well as to identify and analyze the risk factors for weight gain among children in Miramichi in New Brunswick's Horizon Health Network (HHN). This descriptive cross-sectional study was done between 2009 and 2014. The study population was composed of 335 children (185 boys and 150 girls) ages 0 to 42 months and their parents. Overweight and obesity were determined according to World Health Organisation (WHO) criteria adapted for Canada. A logistic regression analysis was performed to determine the risk factors associated with overweight and obesity. The prevalence of risk for overweight is $21 \%$ at birth as opposed to $55 \%$ at 42 months (both sexes together), and the prevalence of risk for overweight including obesity affects $11.8 \%$ of children, that is, $12.7 \%$ of boys as opposed to $10.94 \%$ of girls $(\mathrm{p}<0.0001)$. The prevalence among boys is 1.2 times that among girls. This study also reveals that at 42 months, the average prevalence of obesity is $6.5 \%$ ( $8 \%$ for boys and $5 \%$ for girls). The mothers of overweight children have a higher post-pregnancy BMI $\left(32.78 \pm 4.16 \mathrm{~kg} / \mathrm{m}^{2}\right)$ than do the mothers of children who are a healthy weight $\left(26.17 \pm 7.90 \mathrm{~kg} / \mathrm{m}^{2}\right)(\mathrm{p}<0.0001)$. Moreover, $29.7 \%$ of children are overweight when both parents are overweight compared to $14.97 \%$ when both parents are a healthy weight $(\mathrm{p}<0.05)$. This means that children are twice as likely to be overweight when both parents are overweight compared to children whose parents are a healthy weight. Other-
\end{abstract}


wise, only $17 \%$ of the 335 children assessed in this study were breastfed and started on solid foods in accordance with the WHO recommendations. This study clearly shows that overweight is associated with sex, birth weight, parental obesity, maternal breastfeeding and the age of introduction of solid foods. The prevalence and identification of risk factors for overweight and infant obesity used to screen at-risk children will have the advantage of allowing adapted prevention strategies to be established.

\section{Keywords}

Child, Obesity, Overweight, Risk Factors, Horizon Health

Network, Miramichi, New Brunswick

\section{Introduction}

The prevalence of obesity has increased spectacularly among all age groups, including infants and young children [1]. According to the World Health Organisation (WHO), the number of children in the world ages 0 to 5 who are overweight or obese rose from 31 million in 1990 to 44 million in 2012. WHO forecasts that by 2025 the number of overweight infants and young children will reach 70 million [2]. Canada is not spared by the problem of infant obesity. The prevalence of overweight and obesity among youth has tripled in the last 25 years [3]. From 1985 to 2011, 26\% of youth ages 2 to 17 were overweight or obese [4]. According to the New Brunswick Health Council (NBHC), New Brunswick is second only to Newfoundland and Labrador as the province with the highest rate of obesity in Canada with a prevalence of $34.4 \%$. This prevalence is increasing by about $2 \%$ a year [5]. This rate of infant obesity put Canada in third place in 2014 among the 29 Organisation for Economic Co-operation and Development (OECD) countries participating in the study [6].

Obesity among children is associated to short- and long-term health risks and represents an economic burden on the Canadian healthcare system [7]. The consequences of infant obesity are many, including low self-esteem and problems with socialisation [8], as well as the risk of developing metabolic disorders [9].

Frameworks for preventive actions have been developed to stop this worrisome trend. Most of these action frameworks target school-aged and preschool children. Thus Canada has set up a federal, provincial and territorial framework for action to concentrate efforts to stop juvenile obesity and promote healthy weight [10]. Despite all the work already accomplished, the prevalence of juvenile obesity and overweight continues to rise in Canada. Can factors acting at the beginning of life explain the epidemic of infant obesity? Studies have proven that the factors associated with obesity appear at certain critical periods during childhood. These factors that seem to influence future development of obesity are the prenatal period, early adiposity rebound and puberty [11]. The period from conception to birth is one of rapid growth, cell replication, differentiation 
and functional maturation of the organ systems [12]. These processes are very sensitive to changes in the nutritional environment. Studies have shown that obesity can develop in the first years of life [13]. More and more research is under way on the very early factors that may foster the development of adiposity [13] [14]. Identifying these risk factors is very important because it will clear the way to adopting planned and targeted preventive interventions starting in early childhood, along with early and effective treatment. This is why our study deals with early life (pre- and post-natal) obesity in New Brunswick, in particular the Miramichi region.

The objective of this study was to assess the prevalence of, identify and analyze risk factors for overweight and obesity among children ages 0 to 42 months in Miramichi in the Horizon Health Network (HHN) in New Brunswick.

\section{Material and Methods}

\subsection{Study Type and Population}

This was a descriptive cross-sectional study of a representative sample. The study population was made up of 335 children ages 0 to 42 months and parents, particularly pregnant and nursing women, in the Miramichi region in the province of New Brunswick, Canada.

\subsection{Conduct of the Study}

A questionnaire was created based on recommendations from Health Canada and characteristics related to New Brunswick. The questionnaire was designed to gather information on different variables related both to the parents (age, sex, matrimonial, status, education, profession, monthly household income, tobacco use, weight and height of the parents) and to their infants (age, sex, birth weight, breastfeeding model adopted, age of alimentary diversification, family history of obesity and feeding method).

As for anthropometric variables, weight was measured using Seca Bellissima 841 (Seca gmbh \& CO. Kg, Germany) electronic scales (accuracy $=0.1 \mathrm{~kg}$ ) and height with Soehnle (Medicare bvba, Belgium) standard medical electronic ultrasound height rods (accuracy $=0.1 \mathrm{~cm}$ ). Since 2010, when infants and young children are immunized in Canada the statement of joint principles of the Dieticians of Canada, the Canadian Paediatric Society, the Canadian Pediatric Endocrine Group, the College of Family Physicians of Canada and the Community Health Nurses of Canada has recommended the use of WHO curves adapted for Canada [15] [16] to track and assess the growth of Canadian infants and children in primary care.

According to this document, a young child ages 0 to 5 is considered to be underweight when his or her BMI is below the $3^{\text {rd }}$ percentile. The child is considered to be of healthy weight if his or her BMI is between the $3^{\text {rd }}$ percentile and the $84.9^{\text {th }}$ percentile, and to be at risk of being overweight between the $85^{\text {th }}$ and the $97^{\text {th }}$ percentiles on these curves. Overweight is defined as between the $97^{\text {th }}$ and $99.9^{\text {th }}$ percentiles, and obese as having a BMI exceeding the $99.9^{\text {th }}$ percentile. 
We were thus able to divide the infants and young children into 5 groups. Group 1: underweight children, Group 2: healthy weight, Group 3: at risk for overweight, Group 4: overweight and Group 5: obese.

Variables in the analysis of risk factors were divided into two groups: the dependant variable was BMI (overweight or obesity) among children 0 to 42 months and the explanatory variable was made up of the risk factors associated with overweight and obesity in children of the same age.

Data was recorded and analyzed with SPSS version 21 software. The data was analyzed in two ways: a univariate analysis to look for any correlations between overweight (obesity included) and the different associated variables; a multivariate analysis by logistic regression with a p-value of $5 \%$.

\section{Results}

\subsection{Prevalence of Risk of Overweight, Overweight and Obesity}

The study was of 335 children, 185 boys (55.20\%) and 150 girls (44.80\%), ages 0 to 42 months. The prevalence of the risk of being overweight was $20 \%$ (Figure 1). This prevalence reached $80 \%$ of boys and $90 \%$ of girls in 6 months. After 6 months, it was still high, although it declined slightly to affect $60 \%$ of boys as opposed to $53 \%$ of girls at 12 months. The prevalence of the risk of overweight dropped significantly to $24 \%$ for girls as opposed to $48 \%$ for boys at 18 months (Figure 1). However, at 42 months there was no significant difference in prevalence between girls and boys. However, we noted that the prevalence for both sexes was around 55\%, corresponding to an increase in weight among girls of over $30 \%$, as opposed to only $7 \%$ among boys.

At birth, the prevalence of overweight was about $7 \%$ for boys and $11 \%$ for

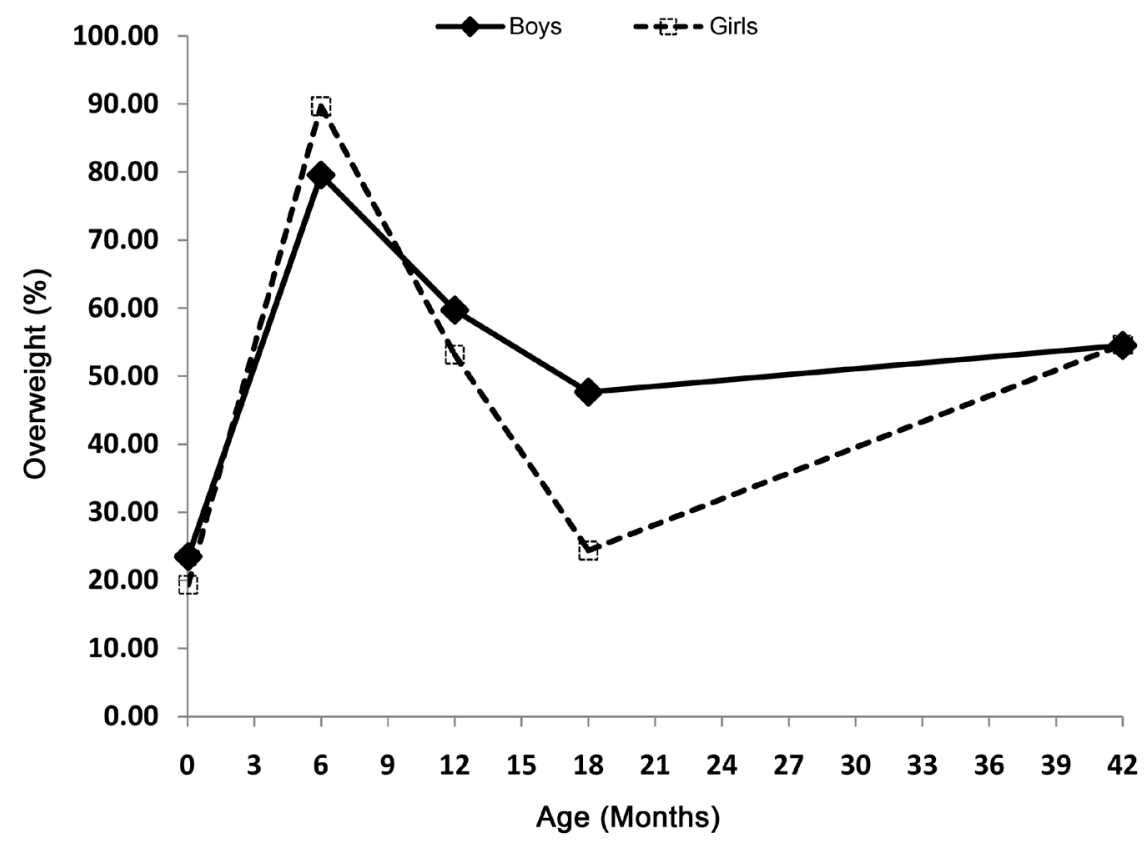

Figure 1. Prevalence (\%) of the risk of being overweight in girls and boys ages 0 to 42 months in the Miramichi region of New Brunswick between 2009 and 2014. 
girls (Figure 2). At 6 months, this prevalence reached 30\% for boys and 32\% for girls. After 6 months, it dropped slightly to $22 \%$ for boys as opposed to $21 \%$ for girls at 12 months. The prevalence of overweight dropped significantly for girls ( $21 \%$ to $7 \%$ ), as opposed to $22 \%$ to $18 \%$ for boys, at 18 months. At 42 months, there was no significant difference between the prevalence among girls and among boys. However, this prevalence was around $12 \%$.

The study results show that the prevalence of obesity was nil for boys at birth and $2 \%$ for girls (Figure 3 ). This increased by $5 \%$ for both boys and girls, reaching $5 \%$ and $7 \%$ respectively. It increased to $10 \%$ for boys at 12 months and stabilised for girls between 6 and 12 months. The prevalence of obesity dropped significantly for girls to $4 \%$ compared with $8 \%$ for boys at 18 months. At 42 months, we saw a slight decrease for boys and a slight increase for girls.

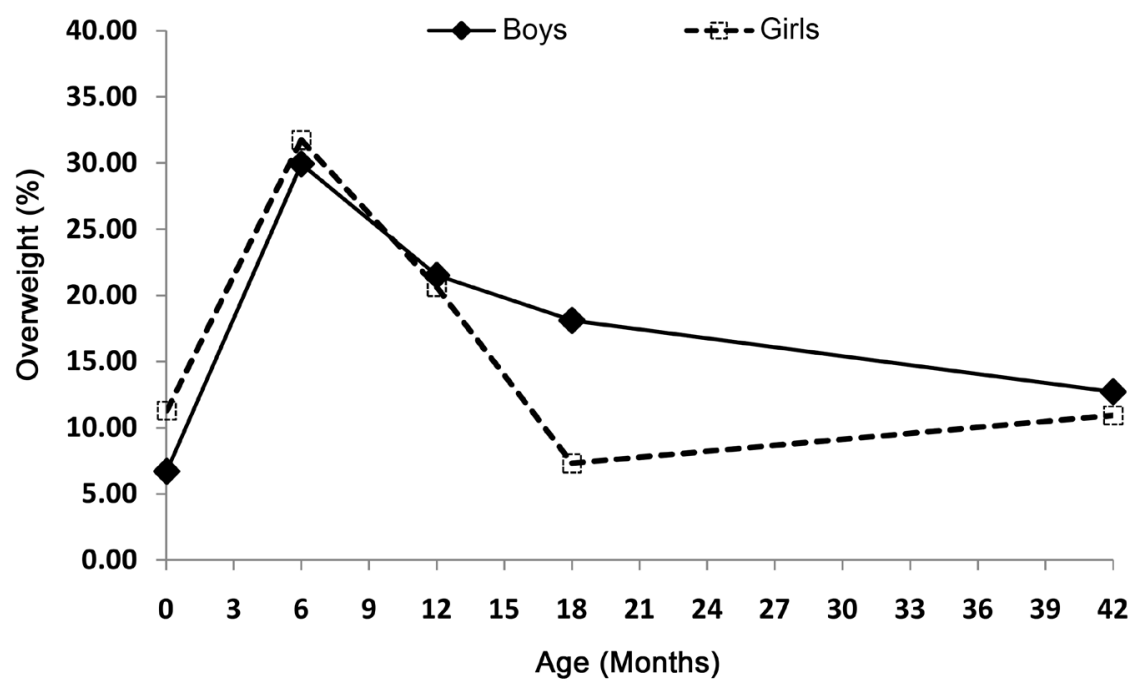

Figure 2. Prevalence (\%) of overweight in girls and boys ages 0 to 42 months in the Miramichi region of New Brunswick between 2009 and 2014.

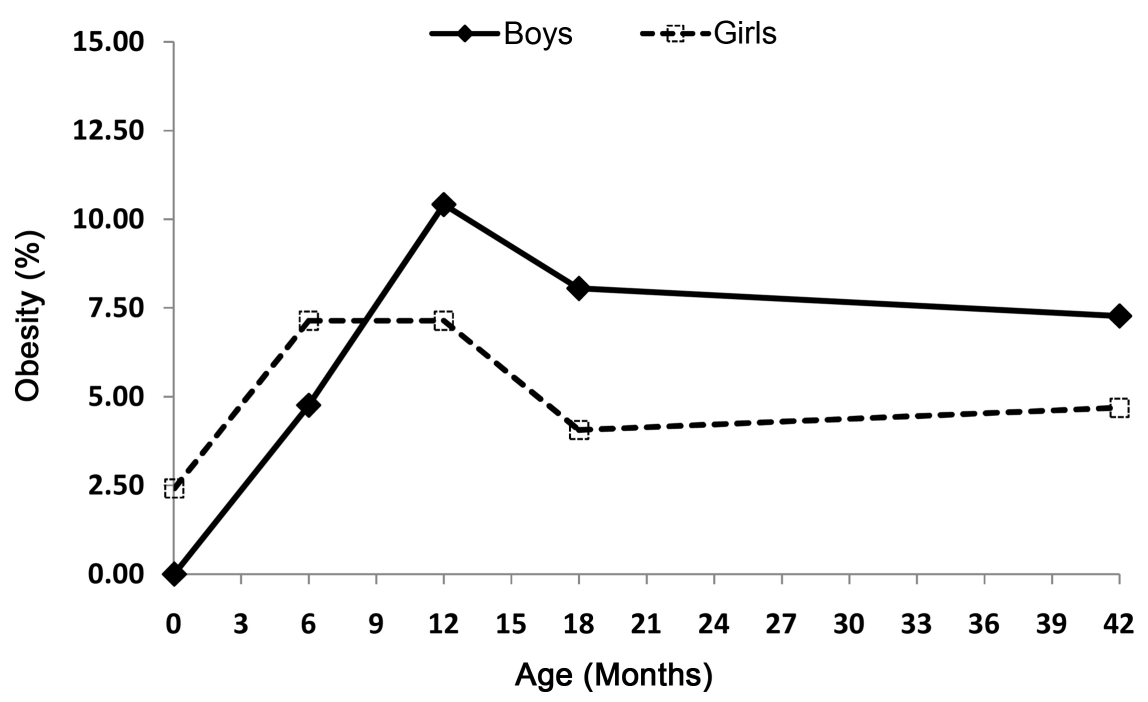

Figure 3. Prevalence (\%) of obesity in girls and boys ages 0 to 42 months in the Miramichi region of New Brunswick between 2009 and 2014. 


\subsection{Parental Obesity}

Maternal BMI was $26.17 \pm 7.90 \mathrm{~kg} / \mathrm{m}^{2}$ pre-pregnancy and $27.64 \pm 8.00 \mathrm{~kg} / \mathrm{m}^{2}$ post-pregnancy. Note on Figure 4 that paternal BMI is higher $(29.25 \pm 7.06$ $\mathrm{kg} / \mathrm{m}^{2}$ ) than maternal BMI.

Mothers of overweight children had a higher pre-pregnancy BMI (32.78 \pm $\left.4.16 \mathrm{~kg} / \mathrm{m}^{2}\right)$ than mothers of children who were a healthy weight $(26.17 \pm 7.90$ $\left.\mathrm{kg} / \mathrm{m}^{2}\right)$. Their BMI was significantly different $(\mathrm{p}<0.0001)$ (Figure 5$)$.

The BMI of mothers of overweight children was significantly different and higher $\left(35.71 \pm 3.16 \mathrm{~kg} / \mathrm{m}^{2}\right)$ even post-pregnancy than that of mothers of children who were a healthy weight $\left(26.17 \pm 7.90 \mathrm{~kg} / \mathrm{m}^{2}\right)(\mathrm{p}<0.0001)$.

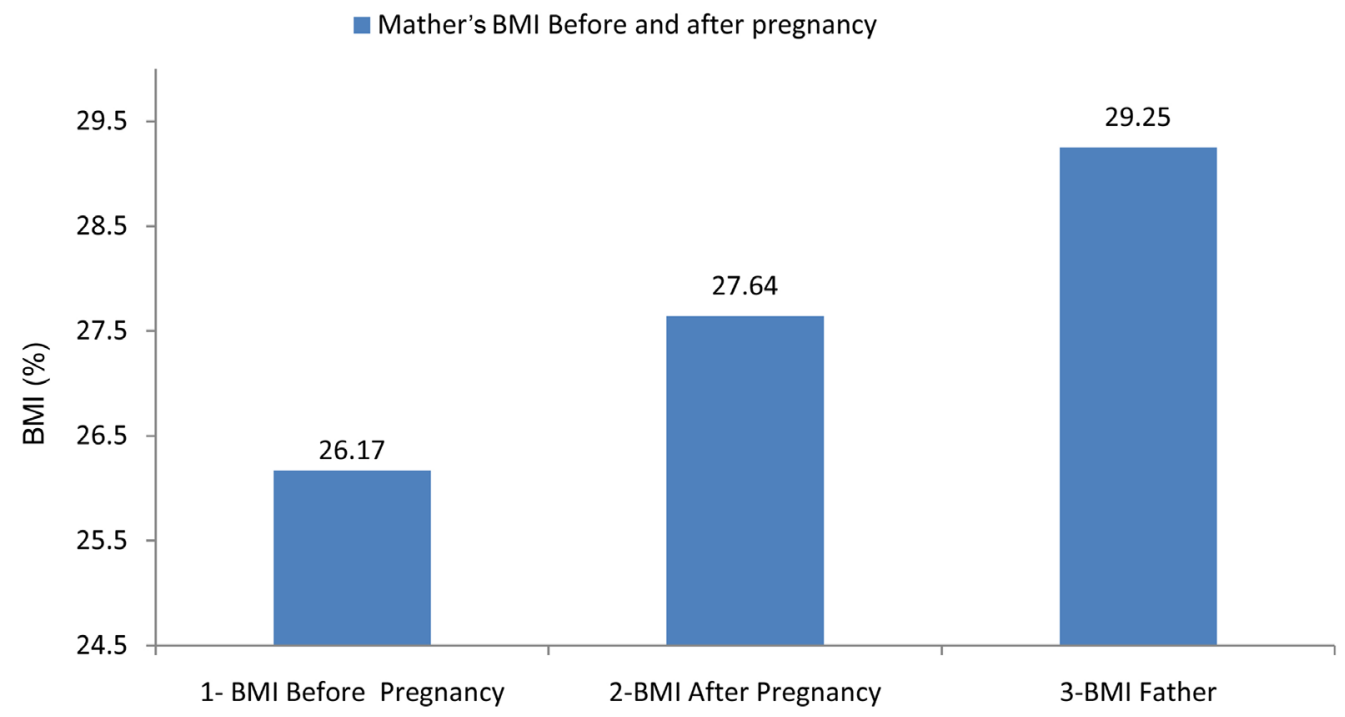

Figure 4. Mother's pre- and post-pregnancy BMI.

Overweight \& healthy children mother's BMI Before \& after pregnancy

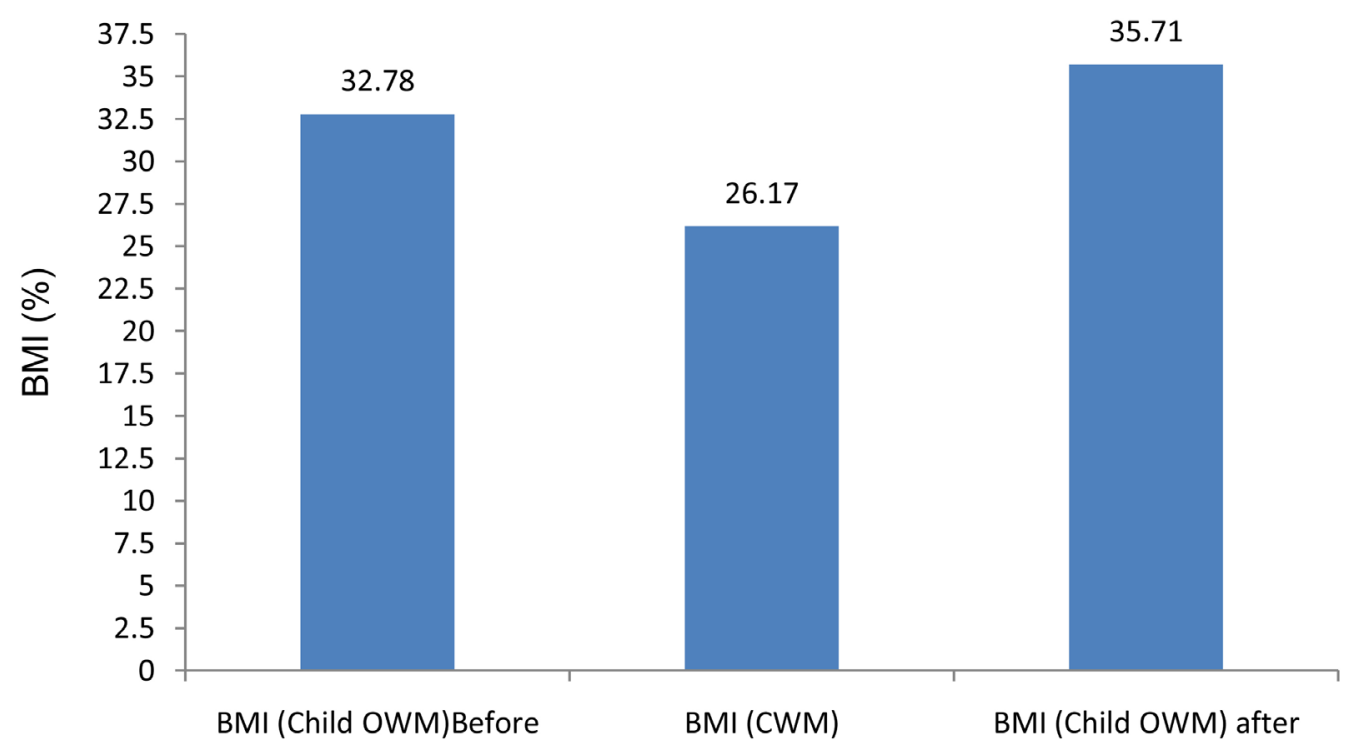

Figure 5. Mother's pre- and post-pregnancy BMI by the weight of the child. 


\subsection{Maternal Breastfeeding and Age of Introduction of Solid Foods}

Only $17 \%$ of the 335 children assessed in this study were breastfed and started on solid foods in accordance with the WHO recommendations. This means that $83 \%$ of the children were not breastfed for the recommended period and consumed solid foods before age 6 months. Also, the period of introducing solids varied between 2 and 18 months, and occurred most frequently before age 6 months.

\subsection{Univariate Analysis of Risk Factors for Overweight}

The univariate analysis of risk factors for overweight showed eight factors significantly associated with overweight (Table 1).

\subsection{Multivariate Analysis of Risk Factors for Overweight}

Table 2 repeats the Odds Ratios adjusted $\left(\mathrm{OR}_{\mathrm{a}}\right)$ and Confidence Intervals at $95 \%$ (CI 95\%) obtained in the last step of the top-down procedure. The multivariate analysis identified four factors significantly associated with overweight in the final model: being male $\left(\mathrm{OR}_{\mathrm{a}}=1.2\right.$; CI $\left.95 \%=[1.1-2.0]\right)$; having a birth weight $<$ $2.5 \mathrm{~kg}$ or $>4.5 \mathrm{~kg}\left(\mathrm{OR}_{\mathrm{a}}=1.6\right.$; CI $\left.95 \%=[1.2-2.3]\right)$; putting on weight excessively during the first two years of life $\left(\mathrm{OR}_{\mathrm{a}}=1.9\right.$; CI $\left.95 \%=[1.6-3.0]\right)$ and a family history of overweight $\left(\mathrm{OR}_{\mathrm{a}}=2.2\right.$; CI $\left.95 \%=[1.7-3.1]\right)$.

Table 1. Factors explaining overweight and obesity among young children ages 0 to 42 months in Miramichi. Univariate logistic regression analysis.

\begin{tabular}{|c|c|c|c|c|c|c|}
\hline \multicolumn{3}{|c|}{$\mathrm{p}<20 \%$} & \multirow{2}{*}{$\begin{array}{c}\% \\
55.2\end{array}$} & \multirow{2}{*}{$\begin{array}{c}\text { OR Brut } \\
1.2\end{array}$} & \multirow[t]{2}{*}{ IC $95 \%$} & \multirow[t]{2}{*}{$P$} \\
\hline Ser & & Boy & & & & \\
\hline sex & & Girl & 44.8 & 1.0 & {$[1.1-2.0]$} & 0.001 \\
\hline \multirow{3}{*}{ Birth weight } & $\checkmark$ & $<2.5 \mathrm{~kg}$ & 6.8 & 0.8 & {$[0.4-1.9]$} & NS \\
\hline & & {$[2.5-4.49 \mathrm{~kg}]$} & 65.0 & 1.0 & & \\
\hline & $\checkmark$ & $>4.5 \mathrm{~kg}$ & 29.8 & 1.6 & {$[1.4-2.6]$} & 0.001 \\
\hline Excessive & $\checkmark$ & Yes & 37.6 & 1.65 & & \\
\hline weight gain & $\checkmark$ & No & 62.4 & 1.0 & [1.4 - 2.9] & 0.001 \\
\hline \multirow{2}{*}{$\begin{array}{c}\text { Family history of } \\
\text { overweight or } \\
\text { obesity }\end{array}$} & $\checkmark$ & Yes & 66.0 & 2.4 & {$[1.1-3.0]$} & 0.001 \\
\hline & $\checkmark$ & No & 37.0 & 1.0 & & \\
\hline Total & $\checkmark$ & Sufficient & 44.0 & 1.0 & & \\
\hline household income & $\checkmark$ & Insufficient & 66.0 & 1.4 & {$[0.4-2.7]$} & 0.001 \\
\hline \multirow{2}{*}{ Smoking } & $\checkmark$ & Yes & 78.1 & 3.9 & & \\
\hline & $\checkmark$ & No & 20.9 & 1.0 & {$[1.5-8.1]$} & 0.01 \\
\hline \multirow{2}{*}{$\begin{array}{l}\text { Breastfeeding for at } \\
\text { least } 6 \text { months }\end{array}$} & $\checkmark$ & Yes & 17.1 & 1.0 & & \\
\hline & $\checkmark$ & No & 83.0 & 4.7 & {$[0.6-5.3]$} & 0.001 \\
\hline \multirow{2}{*}{$\begin{array}{l}\text { Age of alimentary } \\
\text { diversification }\end{array}$} & $\checkmark$ & Before 6 months & 67.9 & 3.9 & & \\
\hline & $\checkmark$ & After 6 months & 17.9 & 1.0 & {$[1.6-4.8]$} & 0.001 \\
\hline
\end{tabular}

ORb: Odds ratio brut; ORb on the other variables in the model; CI 95\%: confidence interval of 95\%. p: degree of significance of the test of $\chi^{2}$, NS: Non Significant. 
Table 2. Factors explaining overweight and obesity among young children ages 0 to 42 months living in Miramichi. Multivariate logistic regression analysis.

\begin{tabular}{|c|c|c|c|}
\hline $\mathrm{p}<5 \%$ & OR adjusted & $C I 95 \%$ & $P$ \\
\hline \multicolumn{4}{|l|}{ Sex } \\
\hline$\checkmark$ Boys & 1.2 & {$[1.1-2.0]$} & 0.001 \\
\hline$\checkmark$ Girls & 1.0 & & \\
\hline \multicolumn{4}{|l|}{ Birth weight } \\
\hline$\checkmark<2.5 \mathrm{~kg}$ & 0.8 & {$[0.5-1.7]$} & 0.001 \\
\hline$\checkmark \quad[2.5-4.49 \mathrm{~kg}]$ & 1.0 & & \\
\hline$\checkmark \quad>4.5 \mathrm{~kg}$ & 1.6 & {$[1.2-2.3]$} & 0.001 \\
\hline \multicolumn{4}{|l|}{ Excessive weight gain } \\
\hline$\checkmark$ Yes & 1.9 & {$[1.6-3.0]$} & 0.001 \\
\hline$\checkmark$ No & 1.0 & & \\
\hline \multicolumn{4}{|c|}{ Family history of overweight or obesity } \\
\hline$\checkmark$ Yes & 2.2 & & \\
\hline$\checkmark$ No & 1.0 & {$[1.7-3.1]$} & 0.001 \\
\hline \multicolumn{4}{|l|}{ Total household income } \\
\hline$\checkmark$ Sufficient & 1.2 & {$[0.60-1.09]$} & NS \\
\hline$\checkmark \quad$ Insufficient & 1.0 & & \\
\hline \multicolumn{4}{|l|}{ Smoking } \\
\hline$\checkmark$ Yes & 1.0 & & \\
\hline$\checkmark$ No & 1.4 & {$[0.52-2.79]$} & NS \\
\hline \multicolumn{4}{|c|}{ Breastfeeding for at least 6 months } \\
\hline$\checkmark$ Yes & 1.0 & {$[0.85-1.96]$} & NS \\
\hline$\checkmark$ No & 1.8 & & \\
\hline \multicolumn{4}{|c|}{ Age of alimentary diversification } \\
\hline$\checkmark$ Before 6 months & 2.1 & {$[1.4-3.6]$} & 0.06 \\
\hline$\checkmark \quad$ After 6 months & 1.0 & & \\
\hline
\end{tabular}

ORa: Odds ratio adjusted; ORa on the other variables in the model; CI 95\%: confidence interval of 95\%. p: degree of significance of the test of $\chi^{2}$, NS: Non Significant.

\section{Discussion}

In this study, the prevalence of overweight including obesity is $12.73 \%$ among boys and $10.94 \%$ among girls based on the WHO criterion adapted for Canada. This prevalence is significantly higher among boys than among girls $(12.73 \%$ as opposed to $10.94 \%$ ), giving boys 1.2 times the risk of being overweight. This means that a boy is 1.2 times more likely than a girl to be overweight. Obesity affects $8 \%$ of boys as opposed to $5 \%$ of girls at 42 months. This masculinisation of obesity may be explained by the child's diet and obesogenic environment. The proportions of overweight and obese children are close to those found in the literature. According to the World Health Organisation (WHO), the prevalence of overweight among infants and young children ages 0 to 5 (obesity included) rose from $4.2 \%$ in 1990 to $6.7 \%$ in 2010; and is expected to affect 70 million children in 2025 [2]. Although these results are not representative of the whole province, they lead us to believe that at age 42 months children in the Miramichi region have an average prevalence (6.5\%) approaching $6.7 \%$ as revealed by WHO (2010) for children ages 0 to 5 . These results not only place the prevalence in this 
region higher than that in other regions of New Brunswick but also situate New Brunswick at a higher prevalence than elsewhere in Canada [15] [16] [17]. At any rate, the prevalence of overweight including obesity in NB remains higher than that in any other province except Newfoundland and Labrador.

The prevalence of overweight is significantly higher among boys than among girls $(12.73 \%$ as opposed to $10.94 \%)$, giving boys 1.2 times the risk of being overweight than girls. This male predominance has not been reported in any other study. Indeed, other studies have reported a female predominance for obesity [18] [19].

The study reveals that a high or low birth weight is a risk factor for infant obesity. In Canada, a healthy birth weight ranges from $2500 \mathrm{~g}$ to $4499 \mathrm{~g}$. In this study, the prevalence of the risk of being overweight is $20 \%$ for children with a birth weight above $4.5 \mathrm{~kg}$ or below $2.5 \mathrm{~kg}$. Thus birth weight has an influence on the weight status of children in Miramichi. These results corroborate those found by Oken et al. [18], who uncovered a correlation between high birth weight and adult obesity. They believe that high birth weight predicts adult obesity, despite the existence a few residual confounding factors (gestational age, smoking and socioeconomic status). A 17-year longitudinal study of over 30,000 newborns showed that the risk of being obese at age 17 increased in proportion to birth weight [19]. Numerous other studies also show that a low birth weight may induce excessive catching up of weight, Oken and al. [18]. This also seems to be related to a higher risk of metabolic syndrome [20]. Hadjiyannakis [21] states that there is a relationship between a baby's weight and his or her body mass index and percentage of fat at adolescence. In other words, a baby who is too large or too small in the mother's belly and at birth compared to the average represented by a certain statistical threshold depending on gestational age has a higher risk of obesity in adolescence. Whitaker et al. [22] also confirm that birth weight can influence the weight profile from early childhood to adulthood. Plourde [23] asserts that a longitudinal study on a sample of 33,413 children showed that those whose birth weight was above 4000 grams had 3 times the chance of being obese at age 17 than those whose birth weight was below 4,000 grams. One of Sorensen's studies [24] also states that a child's birth weight is positively correlated to BMI in adulthood.

Our results reveal that some infants gain weight excessively in the first two years of life. These results agree with those in the literature. Thus, according to Whitaker's analyses [22], there is a very close relationship between the weight of a child at birth, his or her weight during the first years of life and future risk of obesity. The start of life (pre- and post-natal) is a critical period during which environmental factors can program in adaptation mechanisms that will last into adulthood. A child's BMI during the first years of life is also a reliable tool to track the risk of being overweight because an early adiposity rebound is associated with a higher risk of obesity in adulthood [12] [25]. The hypothesis by which an early age of adiposity rebound correlates to later obesity has been verified in a number of studies [26] [27]. This clearly demonstrates that identifying 
critical periods for the development of obesity will enable us to better target preventive measures. The growth of the foetus is largely conditioned by the intra-uterine nutritional environment. However, according to Euser et al. [25], the most critical period for the risk of being overweight in adulthood is not the foetal period but the first months and year post-term.

The prevalence of overweight in the sample increases in proportion to increased corpulence in the parents. Our research showed a positive correlation between excess parental weight and the risk of infant obesity $(\mathrm{OR}=2.2 ; \mathrm{p}<$ $0.001)$. A significant relationship was found between corpulence in the mother and in her children. The percentage of overweight infants and young children in our sample increased in proportion to the corpulence of the parents. We clearly showed that $29.7 \%$ of the children of overweight parents are also overweight, as opposed to $14.97 \%$ when both parents are a healthy weight. Other studies with results similar to ours have shown that when both parents are overweight $49.61 \%$ of their children are overweight, as opposed to $21.04 \%$ when both parents are a healthy weight $(p=0.0042)[20][26]$.

In the family unit, parental obesity is recognized as a major risk factor for adult obesity [28]. The relationship between parental adiposity and that of their children is explained by both shared genetic factors and environmental factors in the family [29] [30]. This suggests a connection to both a genetic predisposition and an obesogenic environment. Similarly, increasing evidence seems to indicate that the environment in the uterus helps to "program" a child's metabolism. Throughout the gestation period, the intra-uterine environment also plays a role in the development of obesity. Differences in growth may be caused by factors such as primiparity, tobacco use, parental age, restrictions in the mother's diet, maternal insulin resistance or gestational diabetes [31]. A number of research projects, including one by Hodges [32], affirm that if a mother gains too much weight during pregnancy the newborn will have an above average birth weight. Maternal overweight before and during pregnancy is significant and revealing because it is associated with poor birth results [28] [29]. Paternal and especially maternal adiposity is correlated with high birth weight in their children [30], suggesting that the intra-uterine environment plays an important role in the later development of obesity. Parental obesity us a major predictive factor of infant obesity, related to the influence of both genetic susceptibility and the environment [33]. Whitaker et al. [22] compared obese children ages 1 to 2 whose parents were of normal weight to those whose parents were obese. Their study shows that the risk of remaining obese into adulthood is only around $10 \%$ if both parents are of normal weight. However, this risk increases to $45 \%$ if one parent is obese and to around $75 \%$ if both parents are. Obesity could be explained by genetic determinism and by the fact that family members share a lifestyle and diet. Overweight would become the norm that members adopt. Heredity may explain excess weight in a family, but shared lifestyle habits could be the triggers. This is why obesity prevention has to start very early, before conception, until birth. Various perinatal factors can affect the risk of being overweight 
or obese later [27].

Our study showed that only $17 \%$ of children are breastfed and undergo alimentary diversification at the age recommended by WHO. Another risk factor for infant obesity is the premature introduction of solid foods, yet the Canadian Paediatric Society recommends starting to introduce food with any consistency around age 6 months. Our study clearly showed that few of the parents of the children concerned followed the WHO recommendations. The number of children who are not breastfed (83\%) and consume solids before age 6 months constitutes a serious concern for the children's future health because the short duration of breastfeeding (less than 6 months) and early introduction of solids contribute to overweight in children [34] [35]. Some authors have blamed the introduction of high energy density foods to infants, and excessive protein contribution from inappropriate milks or food used to provide alimentary diversification in the first year, for rapid weight gain in children [36]. Elsewhere, Frelut [37] demonstrated that breastfeeding for 13 to 25 weeks reduces by $38 \%$ ( $p<$ 0.05 ) the risk of obesity at age 9 . He also found that breastfeeding for longer than 26 weeks reduces the risk by $51 \%(\mathrm{p}<0.05)$. Interviews with the mothers suggest that the early introduction of solid foods is associated with a low socioeconomic level and the perception that the baby is not very fat [36].

Obesity is occurring younger and younger, probably by age 3. Among the guilty environmental factors, methods of feeding infants and young children should be taken into consideration beginning in the first year because this is the period when early adiposity rebound often occurs. This illustrates the importance of putting into place intervention strategies to prevent obesity earlier in early childhood. These intervention strategies must include assessing the nutritional status of the mother before, during and after pregnancy. Low socioeconomic status, smoking and breastfeeding for 6 months are generally risk factors for obesity in the developed countries [36]. Our results do not match data in the literature concerning total household income reflecting the parents' socioeconomic status. On the other hand, still looking at socioeconomic factors, the parents' socio-professional category, while often cited in other studies [35] [38], did not appear here as a factor associated with overweight in children.

\section{Conclusion}

This study highlighted the fact that the prevalence of overweight and obesity among young children in the Miramichi region is clearly higher than is observed in children in the other provinces in Canada. Among the children assessed (96\% are white, $3 \%$ Natives, $1 \%$ non Canadian African and $1 \%$ a student on a temporary visa), the boys are slightly more overweight than the girls. The obesity rate among children ages 0 to 42 months is much higher in Miramichi and the consequences of early childhood obesity can be life-long, requiring more rapid and aggressive interventions targeting this age group. This study also allowed us to identify six factors associated with overweight and obesity: sex, birth weight (low and high), successive weight gain in the first two years of life, parents' weight, 
age of alimentary diversification and maternal breastfeeding. Based on this study, we suggest that a systematic screening tool based on indicators of overweight and obesity be developed and that a committee be formed to determine coaching and treatment strategies targeting children who require special attention, made up of the following: paediatrician, physician, researcher, nutritionist, nurse, representative of civil society.

\section{Acknowledgements}

We are indebted to the Laboratory of Biotechnology, Human Nutrition and Molecular Biology, Faculty of Health Science and Community Services, University of Moncton, New-Brunswick (Canada). This project was also supported by the Consortium National de Formation en Santé. We also thanks Ginette Pellerin, Director of Public Health (Miramichi) and her team (Dr. Michael Dickson, Jessica Sargent, Aline Allain-Doiron, Lucie Chiasson) for assistance and technical Help.

\section{References}

[1] Ogden, C.L., Carroll, M.D., Kit, B.K. and Flegal, K.M. (2012) Prevalence of Obesity and Trends in Body Mass Index among US Children and Adolescents, 1999-2010. Journal of the American Medical Association, 307, 483-490. https://doi.org/10.1001/jama.2012.40

[2] Organisation Mondiale de la Santé (2014) Statistiques sanitaires mondiales 2014. http://www.who.int/gho/publications/world_health_statistics/2014/fr

[3] Twells, L.K., Gregory, D.M., Reddigan, J. and Midodzi, W.K. (2014) Current and Predicted Prevalence of Obesity in Canada: A Trend Analysis. Clinical Medical Association Journal Open, 2, E18-E26.

[4] Roberts, K.C., Shields, M., de Groh, M., Aziz, A. and Gilbert, J.A. (2012) Overweight and Obesity in Children and Adolescents: Results from the 2009 to 2011 Canadian Health Measures Survey. Health Reports, 23, 37-41.

http://www.statcan.gc.ca/pub/82-003-x/2012003/article/11706-eng.htm

[5] UNICEF (2013) Le bien-être des enfants dans les pays riches-Vue d'ensemble comparative. Bilan innocenti 11, Centre de recherche de l'UNICEF, Florence.

[6] Conseil de la Santé du Nouveau Brunswick (2010) Portrait de la santé de la population du Nouveau-Brunswick 2011.

http://www.csnb.ca/portrait-de-la-sante-de-la-population-du-nouveau-brunswick-2 011\#.VWSrS6HeS70

[7] Moffatt, E., Shack, L.G., Petz, G.J., Sauvé, J.K., Hayward, K. and Colman, R. (2011) The Cost of Obesity and Overweight in 2005: A Case Study of Alberta, Canada. Canadian Journal Public Health, 102, 144-148.

[8] World Health Organization (2000) Obesity: Preventing and Managing the Global Epidemic: Report of a WHO Consultation. WHO Technical Report Series 894, World Health Organization, Geneva, Switzerland. http://libdoc.who.int/trs/WHO_TRS_894.pdf

[9] Shin, N.Y. and Shin, M.S. (2008) Body Dissatisfaction, Self-Esteem, and Depression in Obese Korean Children. Journal of Pediatrics, 152, 502-506.

[10] Agence de la Santé Publique du Canada (2011) Mesures de suivi et orientations futures 2011. Freiner l'obésité juvénile: Cadre d'action fédéral, provincial et terri- 
torial pour la promotion du poids santé. Sa Majesté la Reine du Chef du Canada, Ottawa, ON.

http://www.phac-aspc.gc.ca/hp-ps/hl-mvs/framework-cadre/2011/hw-os-2011-fra.p $\underline{\mathrm{hp}}$

[11] Daniels, S.R. (2009) Complications of Obesity in Children and Adolescents. International Journal of Obesity, 33, S60-S65. https://doi.org/10.1038/ijo.2009.20

[12] Dietz, W.H. (1994) Critical Periods in Childhood for the Development of Obesity. American Journal of Clinical Nutrition, 59, 955-959.

[13] Simmons, R. (2008) Perinatal Programming of Obesity. Seminars in Perinatology, 32, 371-374. https://doi.org/10.1053/j.semperi.2008.08.004

[14] Yang, Z. and Huffman, S.L. (2013) Nutrition in Pregnancy and Early Childhood and Associations with Obesity in Developing Countries. Maternal \& Child Nutrition, 9, 105-119. https://doi.org/10.1111/mcn.12010

[15] Les Diététistes du Canada (2014) Les courbes de croissance de l'OMS adaptées pour le Canada. www.dietitians.ca/Secondary-Pages/Public/Who-Growth-Charts.aspx

[16] Les Diététistes du Canada, Société Canadienne de Pédiatrie (2014) Le guide d'utilisation des nouvelles courbes de croissance de l'OMS à l'intention du professionnel de la santé. www.dietitians.ca/Downloads/Public/DC_HealthProGrowthGuideFR.aspx

[17] Agence de la Santé Publique du Canada (2012) Freiner l'obésité juvénile: Cadre d'action fédéral, provincial et territorial pour la promotion du poids santé. http://www.phac-aspc.gc.ca/hp-ps/hl-mvs/framework-cadre/index-fra.php

[18] Oken, E., Levitan, E.B. and Gillman, M.W. (2008) Maternal Smoking during Pregnancy and Child Overweight: Systematic Review and Meta-Analysis. International Journal of Obesity, 32, 201-210. https://doi.org/10.1038/sj.ijo.0803760

[19] Seidman, D.S., Laor, A., Gale, R., Stevenson, D.K. and Danon, Y.L. (1991) A Longitudinal Study of Birth Weight and Being Overweight in Late Adolescence. American Journal of Diseases of Children, 145, 779-781. https://doi.org/10.1001/archpedi.1991.02160070078026

[20] Gillman, M.W. and Mantzoros, C.S. (2007) Breast-Feeding, Adipokines, and Childhood Obesity. Epidemiology, 18, 730-732. https://doi.org/10.1097/EDE.0b013e3181571df0

[21] Xu, S.M. and Xue, Y. (2016) Pediatric Obesity: Causes, Symptoms, Prevention and Treatment. Experimental and Therapeutic Medicine, 11, 15-20. https://dx.doi.org/10.3892\%2Fetm.2015.2853

[22] Whitaker, R.C., Wright, J.A., Pepe, M.S., Seidel, K.D. and Dietz, W.H. (1997) Predicting Obesity in Young Adulthood from Childhood and Parental Obesity. The New England Journal of Medicine, 337, 869-873. https://doi.org/10.1056/NEJM199709253371301

[23] Pourde, G. (2006) Preventing and Managing Pediatric Obesity. Le Medecin de Famille Canadienne, 52, 322-328.

[24] Sørensen, H.T., Sabroe, S., Rothman, K.J., Gillman, M., Fischer, P. and Sørensen, T.I.A. (1997) Relation between Weight and Length at Birth and Body Mass Index in Young Adulthood: Cohort Study. British Medical Journal, 315, 1137. https://doi.org/10.1136/bmj.315.7116.1137

[25] Euser, A.M., Finken, M.J., Keijzer-Veen, M.G., Hille, E.T., Wit, J.M., Dekker, F.W. and on behalf of the Dutch POPS-19 Collaborative Study Group (2005) Associations between Prenatal and Infancy Weight Gain and BMI, Fat Mass, and Fat Dis- 
tribution in Young Adulthood: A Prospective Cohort Study in Males and Females Born Very Preterm. American Journal of Clinical Nutrition, 81, 480-487.

[26] HAS (Haute Autorité de Santé) (6 Octobre 2011) Surpoids et obésité: Repérer plus tôt et mieux prendre en charge, Communiqué de presse.

[27] Shields, M. (2005) Obésité mesurée: L'embonpoint chez les enfants et les adolescents au Canada. Statistique Canada, Ottawa, 36 p.

[28] Hamon, C., Fanello, S., Catala, L. and Parot, E. (2005) Conséquences de l'obésité maternelle sur le déroulement du travail et l'accouchement. Journal de Gynécologie Obstétrique et Biologie de la Reproduction, 34, 109-114.

[29] Vanvrancken-Tompkins, C.L, Melinda, M.A. and Sothern, S. (2006) Prévention de l'obésité chez les enfants de la naissance à cinq ans, Encyclopédie sur le développement des jeunes enfants. Centre d'Excellence pour le Développement des Jeunes Enfants, Montréal, Québec.

[30] Parsons, T.J., Power, C. and Manor, O. (2001) Fetal and Early Life Growth and Body Mass Index from Birth to Early Adulthood in 1958 British Cohort: Longitudinal Study. BMJ, 323, 1331-1335.

https://doi.org/10.1136/bmj.323.7325.1331

[31] Bouglé, D., Vérine-Robine, C. and Duhamel, J.F. (2001) Obésité de l'enfant: Facteurs favorisants, prise en charge. Nutrition Clinique et Métabolisme, 15, 202211.

[32] Kuhle, S., Allen, A.C. and Veugelers, P.J. (2010) Prevention Potential of Risk Factors for Childhood Overweight. Canadian Journal of Public Health. Revue Canadienne de Santepublique, 101, 365-368.

[33] Shi, Y., De Groh, M. and Morrison, H. (2013) Perinatal and Early Childhood Factors for Overweight and Obesity in Young Canadian Children. Canadian Journal of Public Health, 104, e69-e74.

[34] Chaput, J.-P. and Tremblay, A. (2006) Obésité pendant la petite enfance et impact sur le développement de l'enfant. In: Tremblay, R.E., Barr, R.G. and Peters, R.DeV., Eds., Encyclopédie sur le développement des jeunes enfants, Centre d'Excellence pour le Développement des Jeunes Enfants, Montréal, Québec, 1-4. http://www.enfant-encyclopedie.com/Pages/PDF/Chaput-TremblayFRxp.pdf

[35] Tauber, M., Ricour, C. and Bocquet, A. (2007) L'obésité infantile: Nécessité d'un consensus autour de la prévention. Archives de Pédiatrie, 14, 1279-1281.

[36] OGDEN (2010) Obesity and Socioeconomic Status in Children and Adolescents: United States, 2005-2008. National Center for Health Statistics.

[37] Frelut, M.L. (2006) Prise en charge pratique de l'obésité de l'enfant. Archives de Pédiatrie, 13, 641-645.

[38] Hawkins, S.S. and Law, C. (2006) A Review of Risk Factors for Overweight in Preschool Children: A Policy Perspective. International Journal of Pediatric Obesity, 1, 195-209. 
Submit or recommend next manuscript to SCIRP and we will provide best service for you:

Accepting pre-submission inquiries through Email, Facebook, LinkedIn, Twitter, etc. A wide selection of journals (inclusive of 9 subjects, more than 200 journals)

Providing 24-hour high-quality service

User-friendly online submission system

Fair and swift peer-review system

Efficient typesetting and proofreading procedure

Display of the result of downloads and visits, as well as the number of cited articles Maximum dissemination of your research work

Submit your manuscript at: http://papersubmission.scirp.org/

Or contact fns@scirp.org 